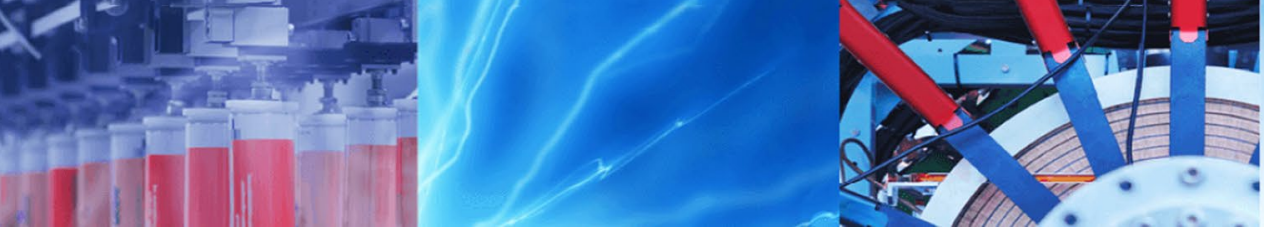

Research Article

\title{
Zinc nanocoated seeds: an alternative to boost soybean seed germination and seedling development
}

\author{
Gabriel Sgarbiero Montanha' ${ }^{1}$. Eduardo Santos Rodrigues ${ }^{1}\left[\right.$. João Paulo Rodrigues Marques ${ }^{1}(\mathbb{D}$. \\ Eduardo de Almeida ${ }^{1}\left[\right.$. Marina Colzato $^{2}\left[\right.$. Hudson Wallace Pereira de Carvalho ${ }^{1}(\mathbb{D}$
}

Received: 25 October 2019 / Accepted: 30 March 2020 / Published online: 9 April 2020

(c) Springer Nature Switzerland AG 2020

\begin{abstract}
In this study, we characterized Zn seed coats adhered on soybean seed surface [Glycine max (L.) Merrill] and then investigated the effects of such coatings on germination and finally monitored the transference of $Z \mathrm{n}$ from the coatings to the seedlings. For that, seeds were coated with $\mathrm{ZnSO}_{4}, 40 \mathrm{~nm} \mathrm{ZnO}$, and $5 \mu \mathrm{m} \mathrm{ZnO}$ at $4 \mathrm{mg}$ of $\mathrm{Zn}$ per $\mathrm{kg}$ of seed. The shape and homogeneity of $Z n$ deposits on the seed surface depended on the type of $Z n$ source. X-ray spectroscopy unraveled that before the germination, $\mathrm{Zn}$ neither crossed the seed coat nor was biotransformed. Regardless of the particle size, $\mathrm{ZnO}$-based treatments increased germination ratio, seedlings root, and shoot development, whereas $\mathrm{ZnSO}_{4}$ suppressed them. After sowing, most of $\mathrm{Zn}$ on the seed coat was transferred to soil, while less than $13 \mathrm{wt} \%$ was assimilated by the seedling 14 days after sowing. Either this minor fraction of $Z n$ was taken up during the imbibition process or absorbed by during seedling growth. Zinc oxide-based treatments represent a viable alternative to $\mathrm{Zn}$ supply in order to boost soybean germination and seedling development.
\end{abstract}

Keywords Zinc $\cdot$ Nanoparticles $\cdot$ Seed coating $\cdot$ XRF $\cdot$ Rhizosphere

\section{Introduction}

Food security is a central issue of the twentieth century [1]. The agricultural output needs to increase by $70 \%$ until 2050 [2-4] to sustain the new 2.3 billion people worldwide in a few decades [5]. A sustainable response to this demand requires higher yields from crops [6] within the same area currently cultivated [3]. Hence, adequate strategies for mineral nutrition of plants are a significant pillar to accomplish these goals [7].

Zinc $(\mathrm{Zn})$ is a micronutrient required for plants [8]. It is present in more than 300 enzymes (e.g., alcohol dehydrogenase and alkaline phosphatase) playing critical roles in the structure and mechanism of DNA-related proteins [9], carbohydrate metabolism, and maintenance of cellular membranes integrity [10]. Despite variations among compartments and across species, $\mathrm{Zn}$ concentration usually ranges from 20 up to $200 \mathrm{mg} \mathrm{Zn} \mathrm{kg}^{-1}$ dry weight shoot and leaf tissues [11], which are inward exported to the agricultural products. However, nearly $50 \%$ of arable soils worldwide are $\mathrm{Zn}$ deficient [12], and thus, it must be supplied through fertilization.

Zinc fertilizers are mostly applied as zinc sulphates, carbonates, and oxides [13], usually employed through soil broadcasting and foliar spraying [14]. Both approaches require driving machines across the field, which increases

Electronic supplementary material The online version of this article (https://doi.org/10.1007/s42452-020-2630-6) contains supplementary material, which is available to authorized users.

Hudson Wallace Pereira de Carvalho, hudson@cena.usp.br| ${ }^{1}$ Laboratory of Nuclear Instrumentation (LIN), Center for Nuclear Energy in Agriculture (CENA), University of São Paulo, Piracicaba, SP 13416-000, Brazil. ${ }^{2}$ Soil Science Department, Luiz de Queiroz College of Agriculture (ESALQ), University of São Paulo, Piracicaba, SP 13418-900, Brazil. 
costs and causes soil compaction. Additionally, soil broadcasting spreads fertilizers everywhere, which implies losses. On the other hand, localized foliar spraying, which delivers the nutrient directly to the plant, can only be accomplished when leaves are already developed. In this latter case, plant performance might be already compromised due to the lack of zinc.

An alternative for micronutrient supply consists of seed treatments (e.g., seed soaking, coating, or priming). Seed treatment is carried out in a warehouse, and therefore, it does not require proper machines trafficking in the field. Besides reducing energetic costs, it prevents soil compaction. Furthermore, it supposedly provides the nutrients to plants embryo even before germination [15]. Adequate $Z n$ content in seeds can ensure higher germination, boost plant development, and enhance protection against pathogens [16].

In this scenario, nanomaterials are a promising source of nutrients for plants. In principle, its size-dependent solubility can yield controlled-release fertilizers, or small particles can be entirely taken up by plants and slowly dissolve at the target tissues [17].

Literature suggests that zinc oxide nanoparticles $(\mathrm{ZnO}$ NPs) can be used as a $Z n$ source for crops [18-20]. Besides, some reports with pinto bean (Phaseolus vulgaris) [21], maize (Zea mays), soybean (Glycine max L.), pigeon pea (Cajanas cajan) and ladies finger (Abelmoschus esculentus) seeds treated with ZnO NPs at $<100 \mathrm{mg} \mathrm{Zn} \mathrm{kg}^{-1}$ claim that it can also grant seeds' antimicrobial protection [20], which could be a desirable double function of ZnO NPs that deserves to be further investigated. On the other hand, phytotoxicity was observed in seeds exposed to higher $\mathrm{ZnO}$ doses [22], and the effects of nanoparticles with both seeds and the soil are still lacking.

Some of the gaps found in the current literature on the effects of nanomaterials on plants regard the employment of realistic concentrations and the presence of adequate experimental controls, i.e., to compare nanoparticles to microparticles and soluble counterparts.

Hence, the present study aimed at: (1) characterizing the zinc-based seed coats deposited on seed surface and check whether impregnated $\mathrm{Zn}$ would pass through the seed coat and reach the interior of cotyledons; (2) establishing the ratio of $\mathrm{Zn}$ in the seed coat that is taken up by seedlings and transferred to soil; (3) assessing whether the seed coating affects seed germination and seedling growth, namely shoot height and root system architectural development; (4) probing the microchemical root environment in terms of $\mathrm{Zn}$ spatial distribution and availability. For that, we employed soybean (Glycine max (L.) Merrill) as a model species. The seed coating procedures adopted in this study mimicked those carried out in farms; the seeds were coated with $\mathrm{ZnSO}_{4}$ and $40 \mathrm{~nm}$ or $5 \mu \mathrm{m} \mathrm{ZnO}$ at $4 \mathrm{~g}$ of
Zn per kg of seeds, which is a dose usually employed for this purpose [15].

Soybean (Glycine max (L.) Merrill) was chosen due to its economic importance, since it is a major protein source for livestock feeding and used in the production of edible oil and biodiesel [23]. In 2018, 341.7 million metric tons of soybean grains were produced worldwide [24].

\section{Materials and methods}

\subsection{Materials}

Three sources of $\mathrm{Zn}$ were used in the present study: $\mathrm{ZnSO}_{4} \cdot 7 \mathrm{H}_{2} \mathrm{O}$ (Dinâmica', Brazil), $5 \mu \mathrm{m} \mathrm{ZnO}$ (Agrichem Company, Brazil), and $40 \mathrm{~nm}$ ZnO (MK Impex Corp, Canada).

\subsection{Characterization of materials}

The particle size of $5 \mu \mathrm{m} \mathrm{ZnO}$ source was determined using a Laser Particle Sizer (ANALYSETTE 22 MicroTec Plus, Fritsch, Germany). An ultrasonic water bath suspended a wet dispersion of the material at $50 \mathrm{~W}$ and $40 \mathrm{kHz}$, exposed to two 7-mW laser beams with $532 \mathrm{~nm}$ and $940 \mathrm{~nm}$ wavelengths and the variations scattered light recorded by a focal plane detector to measure the particles size [25]. Figure $\mathrm{S} 1$ presents the volume distribution of the particle size of the measured samples. The $40 \mathrm{~nm} \mathrm{ZnO}$ was previously fully characterized [26].

\subsection{Seed treatment}

To promote uniform covering of the seeds surface, emulating the procedures carried out by farmers and seed treatment industry [27-30], the seed treatment was performed as described below.

Eighty milligrams (weight $\mathrm{Zn}$ basis) of each $\mathrm{Zn}$ source were added in a plastic vial, and the volume made up to $1 \mathrm{~mL}$ with deionized water. Subsequently, the micrometric and nanometric oxide sources were sonicated using an ultrasonic processor (705 Sonic Dismembrator, Fisher Scientific, USA) operated at $70 \mathrm{~W}$ for three cycles of $15 \mathrm{~min}$ each.

Shortly after, each Zn treatment solution/suspensions were transferred to $200-\mathrm{mL}$ polypropylene bags. Then, $20 \mathrm{~g}$ of soybean seeds (Glycine max (L.) Merrill) cultivar M7739IPRO were added and immediately mixed manually by ca. $1 \mathrm{~min}$. Then, they were dried in a fume hood for $24 \mathrm{~h}$ at room temperature. It represented an exposure of $4 \mathrm{mg}$ of $\mathrm{Zn}$ per $\mathrm{g}$ of seed. Deionized water was used as a control. 


\subsection{Scanning electron microscopy (SEM) analysis of the seed surface}

Seeds were longitudinally sectioned to expose the hilum region. Then, the samples were immediately glued on carbon tape covering aluminum stubs, gold-coated (Baltec model SCD 050), and examined with a scanning electron microscope (JEOL-JSM IT 300) at $15 \mathrm{kV}$. Two seeds from each treatment were scanned.

\subsection{Zinc distribution on coated seeds by X-ray fluorescence spectroscopy microanalysis ( $\mu$-XRF)}

The soybean seeds were cross-sectioned, preserving the hilum region. The samples were placed on an X-ray sample cup (Chemplex no. 1530, USA) sealed with 5- $\mu$ m-thick polypropylene film (Spex SamplePrep, no. 3520, USA). The analysis was performed on a benchtop $\mu$-XRF system (Orbis PC EDAX, USA) furnished with a Rh X-ray tube operated at $40 \mathrm{kV}$ and $900 \mu \mathrm{A}$ and using a $25-\mu \mathrm{m}$-thick Ti filter. Sixty-four points along a ca. $10 \mathrm{~mm}$ internal seed part were investigated by a $30-\mu \mathrm{m} X$-ray beam focused by a polycapillary optical element. The X-ray spectra were acquired during $200 \mathrm{~s}$ using a $30 \mathrm{~mm}^{2}$ silicon drift detector (SDD), with a dead time smaller than $3 \%$. Two independent seeds per treatment were herein probed.

\subsection{Zinc chemical speciation on coated seeds by X-ray absorption near-edge structure (XANES)}

The $\mathrm{Zn}$ chemical environment of treated soybean seed coats was probed by X-ray absorption near edge structure (XANES) prior to sowing. The measurements were performed at the XRF beamline of the Brazilian Synchrotron Light Laboratory (LNLS), which was equipped with Si (111) double-crystal monochromator, KB mirror system providing a $20 \mu \mathrm{m}$ wide $\mathrm{X}$-ray focused beam spot. The spectra were recorded in XRF geometry using a silicon drift detector (SDD; KETEK GmbH, Germany). The calibration was done employing a $\mathrm{Zn}$ foil. The reference compounds were obtained by pelletizing the pristine zinc sources in cellulose ( $0.2 \mathrm{Zn}$ wt\%).

The analysis was carried out in triplicate and acquired XANES spectra were merged to improve the signal-tonoise ratio. The spectra were merged, energy-calibrated using a $\mathrm{Zn}$ foil, and then, normalized using the Athena software within the IFEFFIT package.

\subsection{Cultivation assay}

After the treatments, the soybean seeds were individually sowed in $15-\mathrm{mL}$ vials containing ca. $18 \mathrm{~g}$ sandy oxisol (sand-798; silt-50; clay-152 $\mathrm{g} \mathrm{kg}^{-1}$, respectively) in a growth room at $80.6 \mathrm{~K}\left(27^{\circ} \mathrm{C}\right)$ and under 12-h photoperiod at $250 \mu \mathrm{mol}$ of photons $\mathrm{m}^{-2} \mathrm{~s}^{-1}$, provided by LED lamps (Golden, Brazil) and daily irrigation with deionized water. The soil was chosen due to its low-Zn content $\left(0.8 \mathrm{~g} \mathrm{dm}^{-3}\right)$ in order to assess as the seed treatment a practical approach for $\mathrm{Zn}$ nutrition to soybean plants. The experiment was carried out using twenty-one replicates per treatment $(n=21)$, divided into three groups of seven replicates each. The experiments were repeated twice in two moments of 2018 ( $n=21$ in each treatment). These results are presented independently in the main manuscript and Supplementary Material.

After the germination, the seed coats were carefully removed and dried in a laboratory oven (515/4A, FANEM, Brazil) at $140 \mathrm{~K}\left(60^{\circ} \mathrm{C}\right)$ over $48 \mathrm{~h}$. Then, past 14 days, the plants were removed from the soil, the germination was recorded, and the root tissues were separated from the shoots using a steel blade, photographed for root and shoot length calculation, and then, dried at the same conditions of the seed coats. For the root and shoot heights and area calculation, the ImageJ software version 1.52a was employed.

\subsection{Quantification of Zn by energy-dispersive X-ray fluorescence analysis (EDXRF)}

The plant parts (root, shoot, seed coat) of twenty-one seedlings were grouped for producing the necessary sample mass for the analysis. The plant parts were then ground using a cryogenic grinder for $5 \mathrm{~min}$ pre-cooling and subsequently 5 grinding cycles of 2 min each with $1 \mathrm{~min}$ of cooling between cycles (Spex Sample Prep, Freezer/Mill 6870, USA). One hundred milligrams of the homogenized ground sample was added in the X-ray sample cup (Spex SamplePrep no. 3577, USA) sealed with 5- $\mu$ m-thick polypropylene film (Spex SamplePrep, no. 3520, USA). The Zn content was determined by EDXRF (Shimadzu EDX-720, Japan) using a cellulose-based external calibration curve (Fig. S2).

\subsection{Probing the presence and availability of $\mathrm{Zn}$ on soil and soybean roots}

The soybean seeds were individually sown in acrylic sample holders (rhizoboxes) using the same soil of the experiment described above. An external and removable lid was covered with a 5- $\mu \mathrm{m}$-thick polypropylene film (Spex SamplePrep, no. 3520, USA), and Fig. S3 showed 
the experimental setup. The plants were grown in a growth room at $80.6 \mathrm{~K}\left(27^{\circ} \mathrm{C}\right)$ and under 12-h photoperiod at $250 \mu \mathrm{mol}$ of photons $\mathrm{m}^{-2} \mathrm{~s}^{-1}$, provided by LED lamps (Golden, Brazil) and daily irrigated with deionized water.

After 14 days, the outer lids of the sample holders were removed, and the roots and their immediate neighboring soil were investigated by $X$-ray fluorescence microanalysis $(\mu-X R F$, Orbis PC EDAX, USA). The measurements were performed using a Rh X-ray tube operated at $40 \mathrm{kV}$ and 900 $\mu \mathrm{A}$ and a $25-\mu \mathrm{m}$-thick Ti filter. Each spot was investigated during $120 \mathrm{~s}$ by a $30-\mu \mathrm{m}$ X-ray beam focused by a polycapillary optical element. The $\mathrm{X}$-ray spectra were acquired using a $30 \mathrm{~mm}^{2}$ silicon drift detector (SDD), with a dead time smaller than $5 \%$. The XRF spectra were fitted, and the $\mathrm{Zn}$ Ka net counts were determined. Then, aiming at correcting differences in sample density, the $Z n$ Ka net counts were normalized by Compton Rh Ka net counts. Only the $\mathrm{Zn} \mathrm{Ka}$ signals above the instrumental limit of detection (ILOD) were herein considered. The ILOD was calculated according to Eq. S1.

The experiment was carried out using three seedlings for the controls and the $\mathrm{ZnSO}_{4}$ treatment, and two seedlings micro- and nanometric $\mathrm{ZnO}$. Six soil and six root points were probed per seedling.

\subsection{Quantification of zinc availability on soil through DTPA extraction}

The soils of three independent soybean cultivation assays were air-dried and manually homogenized. Only the soils where soybean seeds germinate was herein considered. Then, $10 \mathrm{~g}$ of air-dried soil and $20 \mathrm{~mL}$ of the DTPA extracting solution $\left(0.005 \mathrm{~mol} \mathrm{~L}^{-1}\right.$ diethylenetriaminepentaacetic acid $+0.1 \mathrm{~mol} \mathrm{~L}^{-1}$ triethanolamine $+0.01 \mathrm{~mol} \mathrm{~L}^{-1}$ calcium chloride at $\mathrm{pH} 7.3$ ) were stirred for $2 \mathrm{~h}$. After filtration, the $\mathrm{Zn}$ content at the supernatant was determined by inductively coupled plasma optical emission spectrometry (ICPOES iCAP 6200, Thermo Scientific) [31].

\subsection{Statistical analysis}

All quantitative data (i.e., seed germination, seedling tissue lengths, zinc probing on roots and soil, and the extractable zinc contents) were subjected to a one-way analysis of variance (ANOVA) plus Tukey tests at $95 \%$ confidence interval. Only the parameters analyzed which presented normal distribution were considered for ANOVA, as probed by the Anderson-Darling normality test, reported on figure labels. The procedures were carried out using Minitab ${ }^{\circ}$ software version 18.1.

\section{Results}

\subsection{ZnO nanoparticles can change seed cuticle surface}

Soybean seeds display a rugulose cuticle pattern at the tegument epidermal cells surrounding the hilum (Fig. 1a, b). The seeds coated with $\mathrm{ZnSO}_{4}$ exhibited a thick layer of residue that partially covered both tegument and hilum (Fig. 1c, d). The seeds coated with ZnO dispersions (Fig. 1e-h) presented two granulometric deposited patterns on the hilum and tegument (Fig. 1e-g). High-magnification images showed that $40 \mathrm{~nm} \mathrm{ZnO}$ dispersion induced cuticle deformation (arrows in Fig. 1h), which was not observed for the other treatments.

\subsection{Tracing $\mathrm{Zn}$ distribution in soybean seeds}

Zinc XRF intensity at each point of the linescan (Fig. 2) is directly proportional to the $Z n$ content. Thus, it allows assessing the $Z n$ distribution along with sectioned soybean seeds. Regardless of the treatment, $\mathrm{Zn}$ presented the maximum count rate at the seed coats, and then, it sharply decreased at the seed coat-cotyledon interface (Fig. 2b-d). The content of $\mathrm{Zn}$ within the cotyledon was similar to the control, independently of the $\mathrm{Zn}$ source used in the coating process. These results show that $Z n$ remained mainly trapped at the seed coat instead of being incorporated by the embryo. Figure S4 presents images recorded for biological replicates, which confirmed the trends described above.

\subsection{Chemical speciation of $\mathrm{Zn}$ coated on soybean seeds}

Figure 3 presents normalized XANES spectra recorded at the hilum of coated and control soybean seeds. Additionally, it shows the spectra for pristine compounds used for seed coating (referred as standards). Since the spectral shape is a fingerprint of the sample chemical environment, it allows inferring whether $\mathrm{Zn}$ was biotransformed in the seeds. The control seed spectra clearly diverged from those acquired on coated seeds. However, the XANES spectra for $\mathrm{ZnSO}_{4}$ and $\mathrm{ZnO}$ coated seeds were similar to their respective pristine compounds. Hence, it indicated that the major fraction of $\mathrm{Zn}$ was not biotransformed while adhered to the soybean seed coat.

\subsection{Effects of seed coating on soybean germination and seedling development}

Seedling development was affected by the seed coating with $\mathrm{Zn}$ sources. Figure $4 \mathrm{a}$ shows both nano- and micrometric $\mathrm{ZnO}$, increased by ca. $40 \%$ of germinated 
Fig. 1 Electron micrographs at low and high magnification of control soybean seed $(\mathbf{a}-\mathbf{b})$, and seeds coated with $\mathrm{ZnSO}_{4}$ (c-d), $5 \mu \mathrm{m} \mathrm{ZnO}$ (e-f), and $40 \mathrm{~nm} \mathrm{ZnO}$ (g-h). Note the rugulose cuticle morphology of the control sample (a-b) and the thick coverage caused by $\mathrm{ZnSO}_{4}(\mathbf{c}-\mathbf{d})$. The points presented with $(*)$ indicates the presence of $\mathrm{ZnO}$ clusters (e-h). The arrows show the deformation of the cuticle. Ep-epidermis; $\mathrm{Hi}-$ hilum

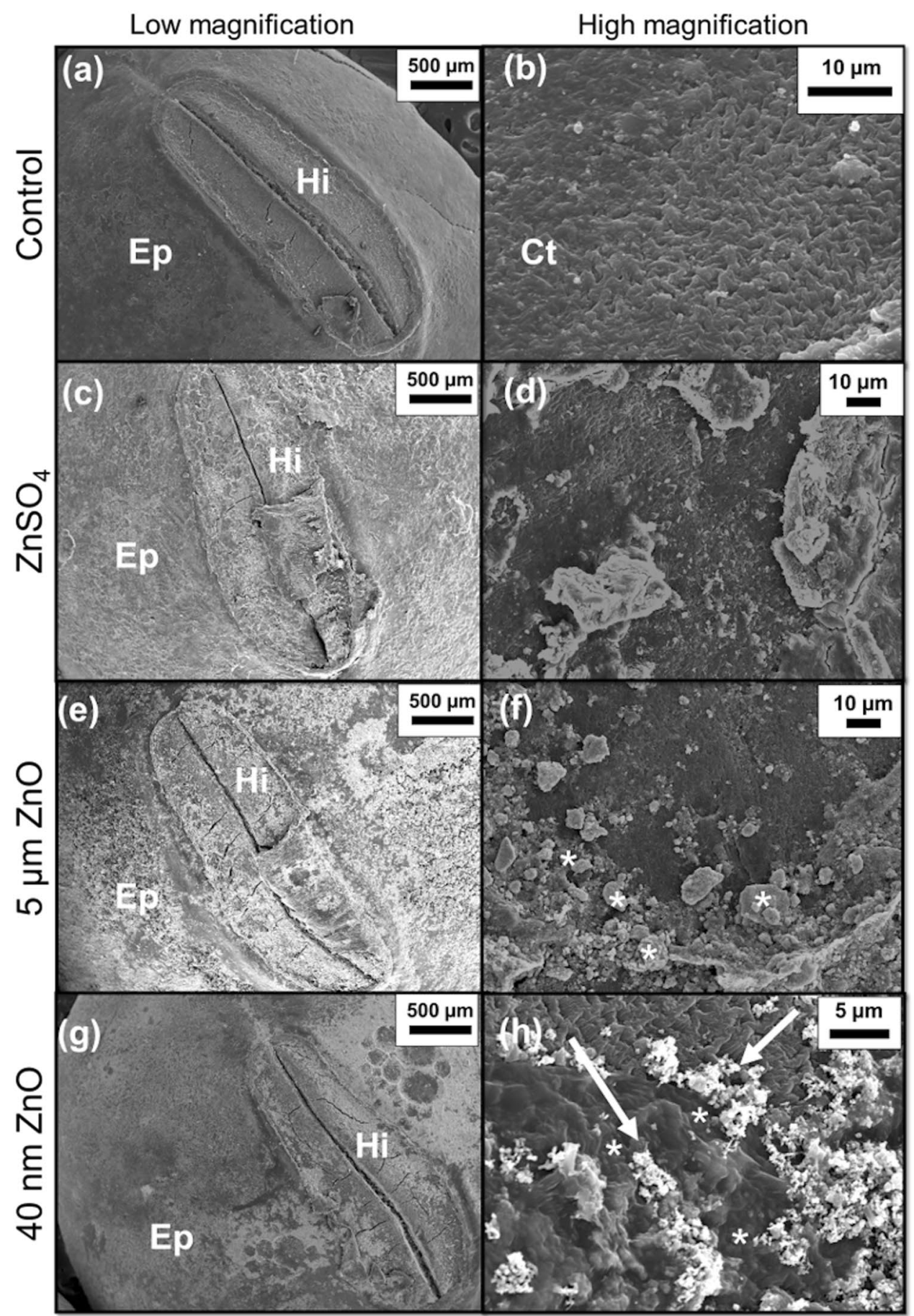

seeds, comparing with the control group. The opposite was observed with the $\mathrm{ZnSO}_{4}$. Figure $\mathrm{S} 5$ presents data for an independent biological replicate where a similar pattern was found. Besides, the length of roots whose seeds were coated with $\mathrm{ZnSO}_{4}$ was lower compared to those coated with $\mathrm{ZnO}$ and the control group (Fig. 4b). Albeit, the root length of plants whose seeds were exposed to nanometric $\mathrm{ZnO}$ was slightly shorter than those coated with micrometric $\mathrm{ZnO}$. On the other hand, the length of the shoots does not statistically differ as an effect of the seed treatments. Figure $\mathrm{S} 6$ presents pictures of the seedlings. The seed coating influenced the architecture of roots and shoots. Seeds coated with $\mathrm{ZnO}$ sources sprout seedlings with more developed roots and shoots, compared to the control. Conversely, the treatment with $\mathrm{ZnSO}_{4}$ was detrimental to these parameters. These factors were quantified and are presented in Fig. S7-it shows root and shoots average mass gain per 
(a) Control

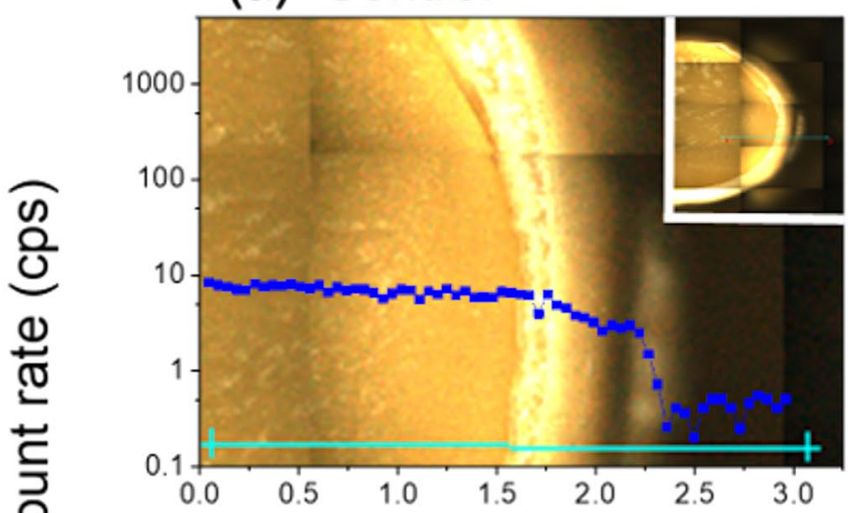

(c) Zinc Oxide $5 \mu \mathrm{m}$

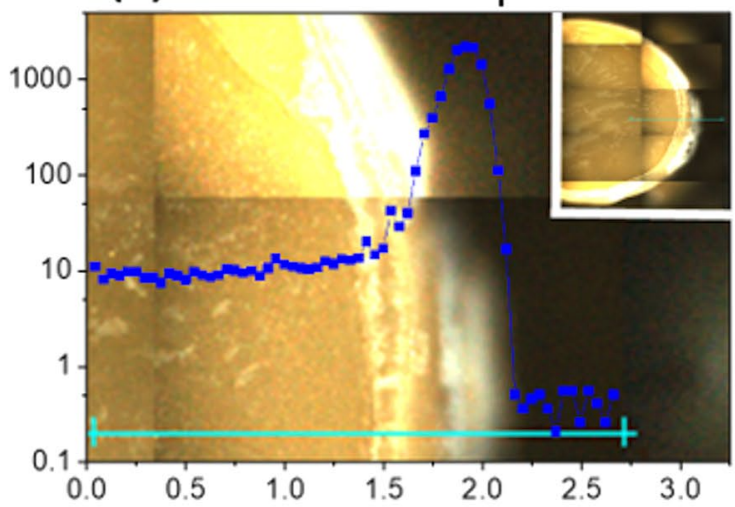

(b) Zinc Sulphate

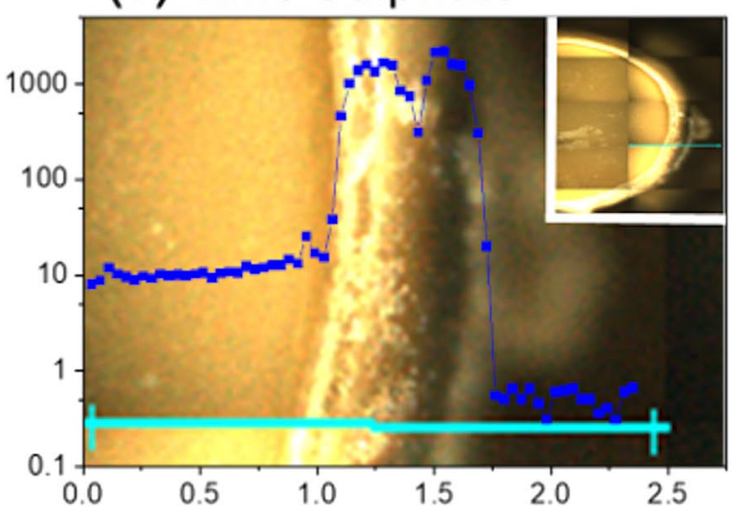

(d) Zinc Oxide $40 \mathrm{~nm}$

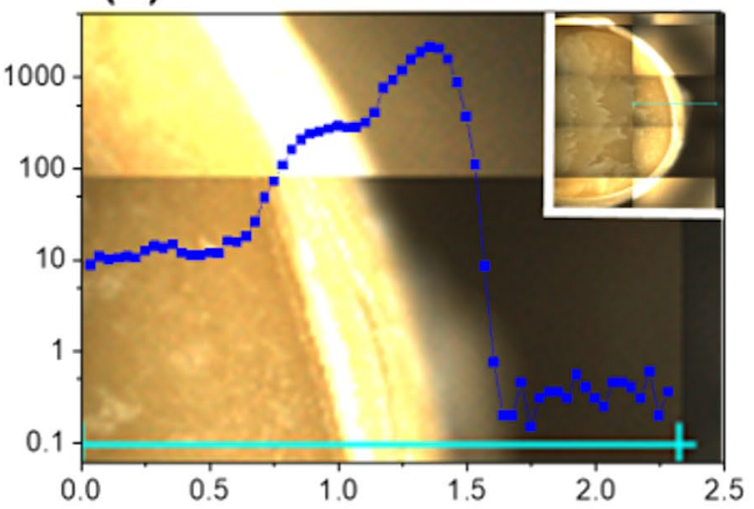

Distance $(\mathrm{mm})$

Fig. 2 XRF linescans showing the $\mathrm{Zn}$ distribution in soybean seeds coated with water (control) (a), $\mathrm{ZnSO}_{4}$ (b), $5 \mu \mathrm{m} \mathrm{ZnO} \mathrm{(c),} \mathrm{and} 40 \mathrm{~nm}$ $\mathrm{ZnO}$ (d) at $4 \mathrm{~g}$ of $\mathrm{Zn}$ per $\mathrm{kg}$ of seeds. Regardless of the $\mathrm{Zn}$ source,

plant. Seedlings treated with $\mathrm{ZnO}$ performed better than control and those coated by $\mathrm{ZnSO}_{4}$.

\subsection{Zinc mass balance}

Table 1 shows the comparison between $\mathrm{Zn}$ content applied and found on soybean seeds and its respective losses during coating. The coating process yield, i.e., the fraction of $Z n$ effectively transferred to the seed during the coating procedure, followed the order $\mathrm{ZnSO}_{4}(89 \%)>$ nano $\mathrm{ZnO}(79 \%)>$ micrometric $\mathrm{ZnO}(48 \%)$. The fraction of $\mathrm{Zn}$ that was not transferred to the seed remained adsorbed on the walls of vials, pipette pointer, and the in the bag used in the processing.

Table 2 presents the $\mathrm{Zn}$ content balance in plants sprout from coated seeds. We determined the partitioning in roots, shoots, seed coats, and soil 8 days after sowing. Regardless of the source used to prime the seeds, the major fraction of $\mathrm{Zn}(>80 \%)$ was found in soil, only ca. 15\% the number ofcounts was higher at the seed coat and hilum region. Co-cotyledons; Te-tegument

of the $\mathrm{Zn}$ was in tissues. It is worth noting that plants that received $\mathrm{ZnSO}_{4}$ presented more $\mathrm{Zn}(12 \%)$ in shoot than those coated with nano- and micrometric $\mathrm{ZnO}$ (ca. $4 \%$ ). On the other hand, $\mathrm{Zn}$ from oxide sources remained mostly in the seed coat than in living tissues. Table S1 presents the mass balance in milligrams (mg), and S2 shows that independent experiments found similar patterns.

\subsection{Probing the presence and availability of $\mathrm{Zn}$ in soil}

Figure 5 a shows the experimental setup built to evaluate the presence of $\mathrm{Zn}$ in the rhizosphere of soybean plants whose seeds were coated with $\mathrm{Zn}$ sources. Plant roots and soil were probed in situ by $\mu$-XRF. Zinc was detected in most of the investigated root tissue and soil points (Fig. 5b). The $\mathrm{Zn}$ counts in the different probed points did not follow a normal distribution; hence, it was not possible to compare the average $\mathrm{Zn}$ counts using ANOVA. On the 
Fig. 3 Zn K-edge XANES spectra recorded at the seed coat of control soybean seeds and seeds coated with $\mathrm{ZnSO}_{4}$ $40 \mathrm{~nm} \mathrm{ZnO}$ and $5 \mu \mathrm{m} \mathrm{ZnO}$ at $4 \mathrm{~g}$ of $\mathrm{Zn}$ per $\mathrm{kg}$ of seeds. The control group was exposed only to deionized water. The blue circle indicates where the $X$-ray beam was probed. There is no evidence of $\mathrm{Zn}$ biotransformation on the seed surface

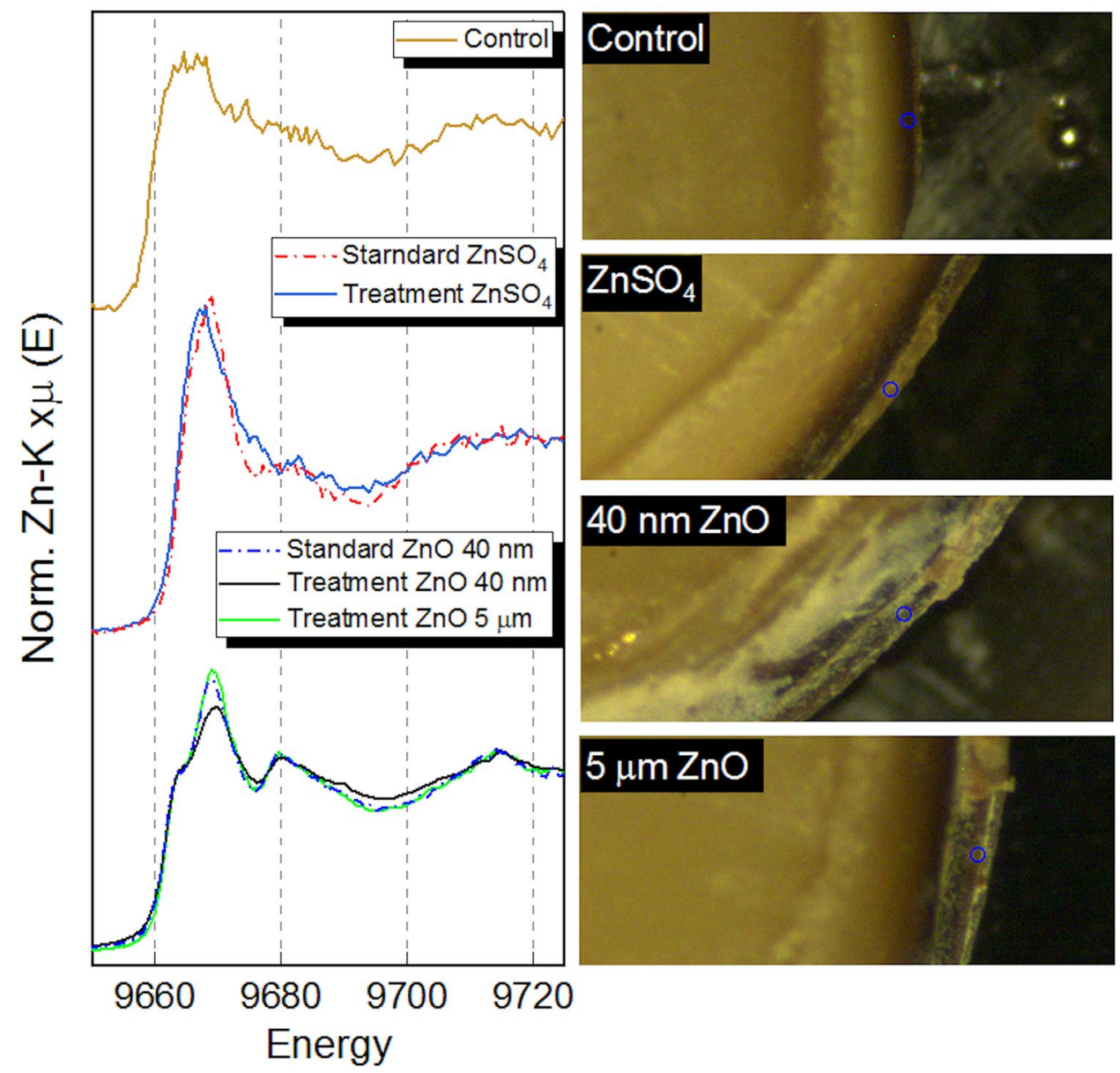

(a)

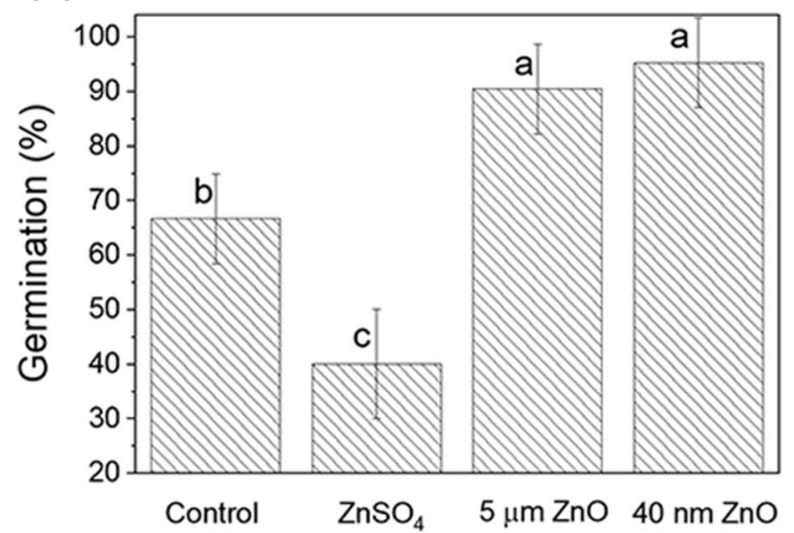

(b)

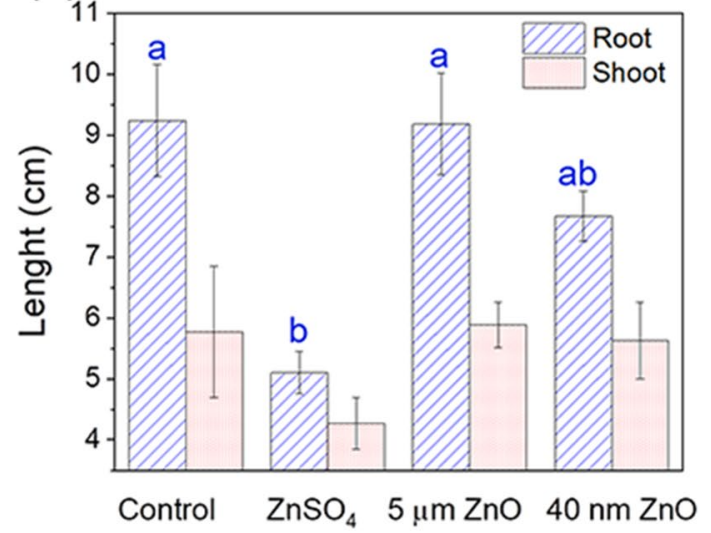

Fig. 4 Germination percentage (a) and root/shoot length (b) of soybean plants exposed to seeds coated with $\mathrm{ZnSO}_{4}(\mathbf{c}-\mathbf{d}), 5 \mu \mathrm{m}$ $\mathrm{ZnO}(\mathbf{e}-\mathbf{f})$, and $40 \mathrm{~nm} \mathrm{ZnO}(\mathbf{g}-\mathbf{h})$ at $4 \mathrm{~g}$ of $\mathrm{Zn}$ per $\mathrm{kg}$ of seeds. The data were subjected to one-way ANOVA and Tukey post-compari- son test with a $95 \%$ confidence interval. The degrees of freedom, $p$ value, and $F$ are $\mathbf{a}(11,<0.001,25.38)$ and $\mathbf{b}(11,0.04,10.29$-root; $11,0.113,2.75$-shoot). Note that variations on soybean shoot length (b) does not present statistical significance 
Table 1 Zinc losses during the seed coating with $\mathrm{ZnSO}_{4}, 5 \mu \mathrm{m} \mathrm{ZnO,}$ and $40 \mathrm{~nm} \mathrm{ZnO}$ at $4 \mathrm{~g}$ of $\mathrm{Zn}$ per $\mathrm{kg}$ of seeds

\begin{tabular}{llll}
\hline & Applied (\%) & Recovered (\%) & $\begin{array}{l}\text { Process } \\
\text { losses } \\
(\%)\end{array}$ \\
\hline Control & - & - & - \\
$\mathrm{ZnSO}_{4}$ & 100 & 89 & 11 \\
$5 \mu \mathrm{m} \mathrm{ZnO}$ & 100 & 49 & 51 \\
$40 \mathrm{~nm} \mathrm{ZnO}$ & 100 & 80 & 20 \\
\hline
\end{tabular}

The control group was exposed only to deionized water. The losses occurred due to the transference of zinc to the materials used in the process, i.e., bags, vials, and pointers. It represents the total zinc content of each tissue from twenty-one samples

Table 2 Zinc mass balance in the root, shoot, seed coat, and soil of germinated seeds coated with $\mathrm{ZnSO}_{4}, 5 \mu \mathrm{m} \mathrm{ZnO}$, and $40 \mathrm{~nm} \mathrm{ZnO}$ at $4 \mathrm{~g}$ of $\mathrm{Zn}$ per $\mathrm{kg}$ of seeds

\begin{tabular}{llllll}
\hline & Seeds (\%) & Shoot (\%) & Root (\%) & Coat (\%) & Soil (\%) \\
\hline Control & 100 & - & - & - & - \\
ZnSO $_{4}$ & 100 & 13 & 0 & 3 & 84 \\
$5 \mu \mathrm{m} \mathrm{ZnO}$ & 100 & 4 & - & 10 & 85 \\
$40 \mathrm{~nm} \mathrm{ZnO}$ & 100 & 4 & 0 & 11 & 85 \\
\hline
\end{tabular}

The control group was exposed only to deionized water. It represents the total zinc content of each tissue from twenty-one samples

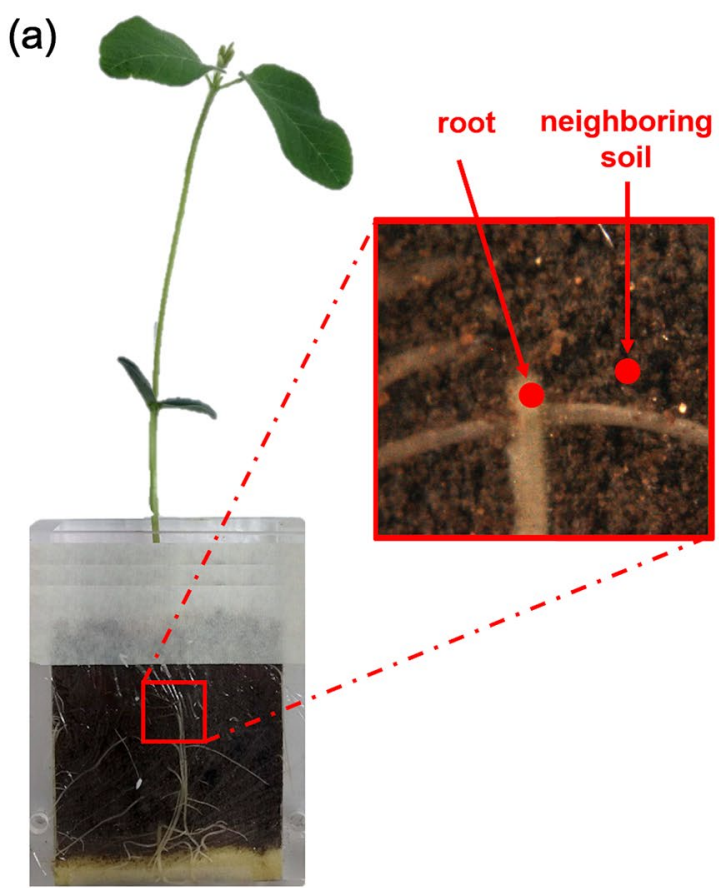

Fig. 5 Detailed view of rhizobox where XRF spectra were collected at soybean roots and neighboring soils (a). The presence or absence of $\mathrm{Zn}$ expressed as a percentage of the probed points ( $n=18$ for the controls and $\mathrm{ZnSO}_{4}$, and $n=12$ for micro and nano), other hand, the median number of counts for the probed points (Fig. 5b) was higher in plants and soil that received the treatments. Thus, the $\mathrm{Zn}$ applied via the seed coat was transferred to plant tissue and rhizosphere soil.

Figure 6 presents the availability of zinc on the soil by DTPA extraction 15 days after sowing. Regardless of the $\mathrm{Zn}$ source (despite the statistical differences between them), a minor fraction (4 to $13 \%$ ) of the $\mathrm{Zn}$ remained available for plants.

\section{Discussion}

The chosen priming method was a proxy of the actual approach carried out by end-user farmers and in industrial seed treatment [27-30]. Such as in practical seed treatment, the procedure intends to transfer the coating to the seed surface rather than trigging seed germination during priming. Therefore, the amount of water and time of soaking was smaller and shorter, respectively, than those commonly reported in the literature [26, 32-34]. Additionally, an imbibed seed presents reduced mechanical resistance and is more prone to the attack of pathogens.

The $\mu$-XRF linescans revealed that the seed coat prevented the $\mathrm{Zn}$ movement towards the cotyledon.

(b)

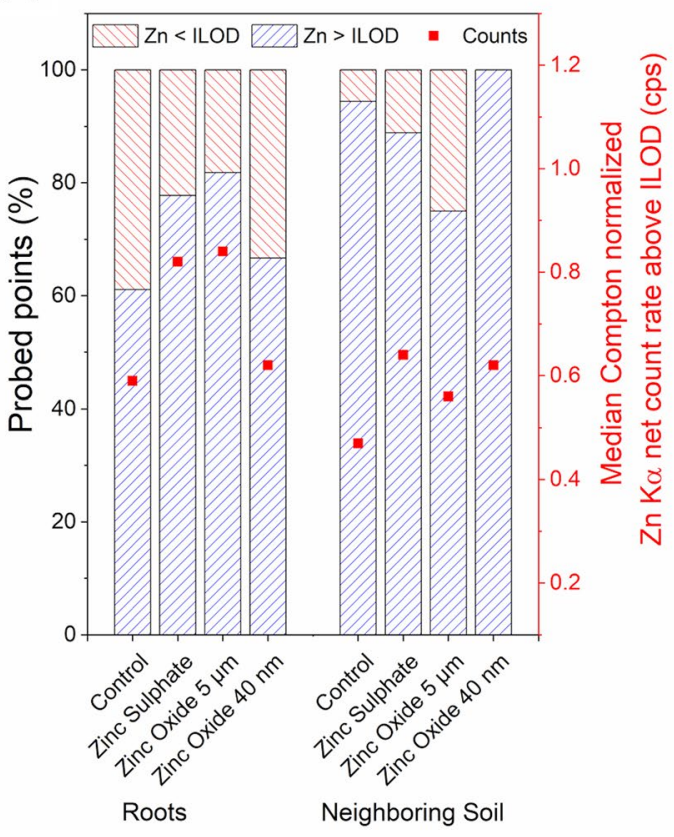

and on the left axis is shown the median normalized $\mathrm{Zn}$ number of counts found above the ILOD while the amount expressed as cps is shown in the right axis (b). The amount of $\mathrm{Zn}$ was higher in the points probed in primed samples

\section{SN Applied Sciences}




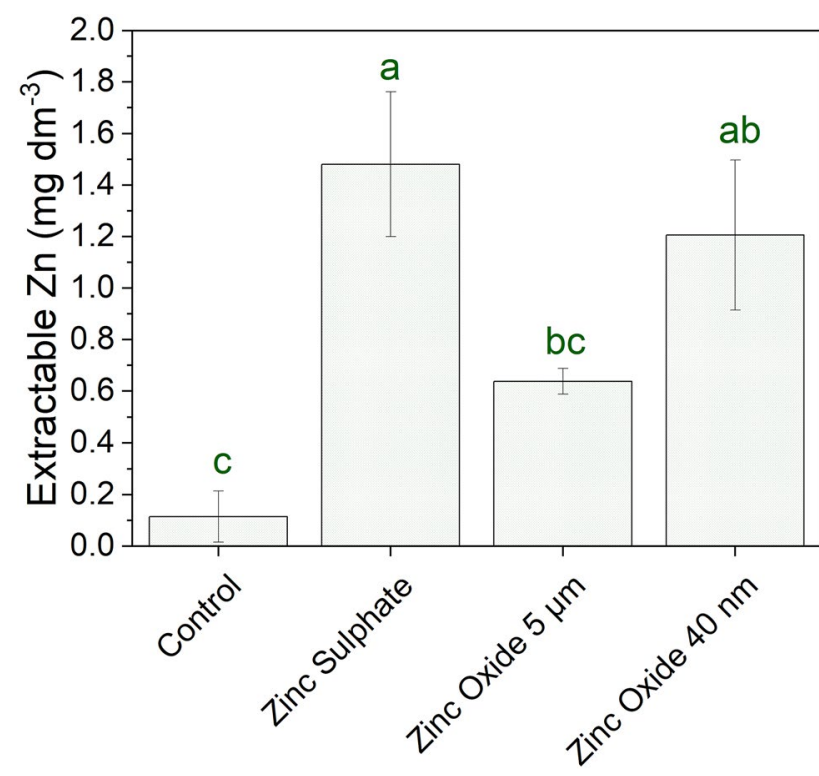

Fig. 6 DTPA extracted $\mathrm{Zn}$ in soils cultivated with primed $\mathrm{ZnSO}_{4}$, $5 \mu \mathrm{m} \mathrm{ZnO}$, and $40 \mathrm{~nm} \mathrm{ZnO}$ and control seeds. The data were subjected to one-way ANOVA plus a Turkey post-comparison test with a $95 \%$ confidence interval. The degrees of freedom, $p$-value, and $F$ are $10,0.001$, and 18.54

According to the literature, the seed coat acts as a barrier for seed protection, due to its lignified tissues (e.g., sclerenchyma) [35], while the hilum is the porous tissue responsible for the imbibition processes [36]. Similar trends were found by $\mu$-XRF maps of common bean (Phaseolus vulgaris) seeds soaked with $\mathrm{CuSO}_{4}$ and $25 \mathrm{~nm} \mathrm{CuO}$ at $1000 \mathrm{mg} \mathrm{Cu} \mathrm{L}^{-1} ; 40 \mathrm{~nm} \mathrm{CuO}$ at $5000 \mathrm{mg} \mathrm{Cu} \mathrm{L}^{-1} ; 20 \mathrm{~nm}$ $\mathrm{Fe}_{3} \mathrm{O}_{4}$ and $\mathrm{Fe}_{3} \mathrm{O}_{4}$ at $1000 \mathrm{mg} \mathrm{Fe} \mathrm{L}^{-1}$; and $\mathrm{ZnSO}_{4}$ and 20, 40, and $60 \mathrm{~nm} \mathrm{ZnO}$ at $5000 \mathrm{mg} \mathrm{L}^{-1}$. In all cases, the applied compounds remained on the seed coat, mainly concentrated in the hilum region [26, 33, 37]. These results are reinforced by the SEM images, where the coated $\mathrm{ZnSO}_{4}$ formed a thick coverage on the soybean seed tegument, whereas for nano- and micro-ZnO dispersion, it was surrounding the hilum in the form of clusters.

Additionally, XANES revealed that $\mathrm{Zn}$ was not biotransformed by the coating process. These results differ from those obtained for common beans (Phaseolus vulgaris), which showed biotransformation of the coated $\mathrm{Cu}, \mathrm{Fe}$, and $\mathrm{Zn}[26,33,37]$. Furthermore, Cu XANES speciation in Arabidopsis thaliana seeds soaked in $\mathrm{CuO}$ nanoparticles at 20 and $50 \mathrm{mg} \mathrm{L}^{-1}$ revealed Cu mainly as $\mathrm{CuO}$, but also small fractions as $\mathrm{Cu}_{2}(\mathrm{OH}) \mathrm{PO}_{4}$, Cu acetate, and $\mathrm{Cu}_{2} \mathrm{O}$ [38]. This contrast might be related to the time of soaking and water content employed in the coating process. Another possible explanation to the non-transformation relies on the soybean cuticle composition that may interfere in the $\mathrm{Zn}$ absorption. Further studies are requested to clarify this topic.

The mass balance reveals that most of $\mathrm{Zn}$ at the coated seeds is transferred to the soil after sowing. Therefore, both $\mathrm{ZnSO}_{4}$ and $\mathrm{ZnO}$ may modify the soil $\mathrm{pH}$ and concentration gradient microenvironment around the seeds [39]. Our study shows that $\mathrm{ZnSO}_{4}$ resulted in lower germination percentage and constrained plant development. Similar results were found for rice (Oryza sativa L.) [40] and common bean (Phaseolus vulgaris) [26]. Higher doses of $\mathrm{ZnSO}_{4}$ are reported to cause phytotoxicity due to salt accumulation on cell walls and induce several modifications to plant metabolism and growth. Also, phytotoxicity was found in radish (Raphanus sativus), rape (Brassica napus), ryegrass (Lolium perenne), lettuce (Lactuca sativa), corn (Zea mays), and cucumber (Cucumis sativus) seeds soaked in $35 \mathrm{~nm}$ $\mathrm{Zn}$ and $20 \mathrm{~nm} \mathrm{ZnO}$ at $2000 \mathrm{mg} \mathrm{L}^{-1}$ for $2 \mathrm{~h}$, in which the half-maximal inhibitory concentration $\left(\mathrm{IC}_{50}\right)$ on seed germination and root growth was ca. $50 \mathrm{mgL}^{-1}$ for radish and roughly $20 \mathrm{mg} \mathrm{L}^{-1}$ for rape and ryegrass [22]. On the other hand, our study showed that $\mathrm{ZnO}$ micro- and nanocoated seeds exhibited germination percentage and seedling development higher than those exposed to $\mathrm{ZnSO}_{4}$ and the control group. Likewise, peanut (Arachis hypogaea) seeds soaked during $3 \mathrm{~h}$ in $25 \mathrm{~nm} \mathrm{ZnO}$ at $1000 \mathrm{mg} \mathrm{L}^{-1}$ presented a higher germination ratio, higher stem length, and root growth compared to those exposed to $\mathrm{ZnSO}_{4}$ [19].

The mass balance showed that an important fraction of coated $\mathrm{Zn}$ remained adhered to the seed coat after germination. In addition, the $Z n$ content in the shoots exposed to both $\mathrm{ZnO}$ sources is around four-fold lower than those exposed to $\mathrm{ZnSO}_{4}$. This result suggests that the solubility of $\mathrm{Zn}$ source is a factor limiting $\mathrm{Zn}$ uptake by plants. It was also reported $\mathrm{Zn}$ and $\mathrm{Cu}$ increase in maize (Zea mays) root and shoot after seed coating with $\mathrm{CuCO}_{3}$ and $\mathrm{ZnO}$ at 0.14 , $0.28,0.56,1.12$, and $2.24 \mathrm{mg} \mathrm{seed}^{-1}$ [29] and 0.55, 1.10, $2.20,4.40$, and $8.80 \mathrm{mg} \mathrm{seed}^{-1}$ [41], respectively.

Conversely, although we found higher nano- and micrometric $\mathrm{ZnO}$ source losses during the coating process compared to $\mathrm{ZnSO}_{4}$, the germination and plant development of the former seed treatments were higher than the latter one. Then, it is possible to assume herein that the agronomic efficiency of the process will not be directly proportional to the mass of coating material adhered to the seed.

Despite the increase in the total $\mathrm{Zn}$ content in soil due to the coating input, the latter contribution represents only around $5 \mu \mathrm{g}$ of $\mathrm{Zn}$ per $\mathrm{kg}$ of soil. In this case, the $\mathrm{Zn}$ might remain in the rhizosphere. The $\mu$-XRF intensities recorded at the roots and neighboring soil showed that the seed coating enriches the rhizosphere with Zn (Fig. 5).

We found higher DTPA extractable $\mathrm{Zn}$ fractions for soils that received seeds coated with $\mathrm{ZnSO}_{4}$ and nanometric $\mathrm{ZnO}$. It is known that charges in oxisols are highly 
dependent on functional groups in organic matter and the surfaces of $\mathrm{Fe}, \mathrm{Al}$, and $\mathrm{Mn}$ (hydr)oxides [42]; such charges can immobilize $\mathrm{Zn}^{2+}$. It has been previously reported that due to its higher surface-to volume ratio, nano- $\mathrm{ZnO}$ is rapidly transformed in soil [43], which may imply on its higher availability than micrometric $\mathrm{ZnO}$ source.

\section{Conclusions}

This study showed that the three zinc sources at $4 \mathrm{mg} \mathrm{g}^{-1}$ affected soybean seed coating germination, as well as soybean early-seedling development. Regardless of the source, the $\mathrm{ZnO}$ seed treatment boosted the germination by ca. $40 \%$, compared to the control; it yielded longer roots with more developed architecture, compared to the control. The opposite was observed for $\mathrm{ZnSO}_{4}$, which clearly provided a toxic environment.

Counterintuitively, $\mathrm{Zn}$ seems not to cross the seed coat and enrich the cotyledons. It remained on the seed coat in their pristine chemical form. Besides, only a small fraction of the $\mathrm{Zn}$ applied to seeds was transferred to the seedling tissues. Most of it remained adhered on the seed coat or was transferred to the soil after sowing.

In addition to physiological pieces of evidence, $\mathrm{Zn}$ fertilization can be discussed thanks to in situ microprobe $\mathrm{X}$-ray fluorescence. Although the Tukey test has not shown statistical difference from control, the average $\mathrm{Zn}$ was higher in roots and soil of rhizoboxes that received the treated seed. Hence, the $\mathrm{Zn}$ employed in the treatment is either transferred during the imbibition or it provides a fertile microenvironment that favors the initial seedling development. Perhaps, one of the leading advantages seed coatings consists in delivering the desired nutrient in the soil region where the roots will grow. In this context, $\mathrm{ZnO}$ treatments represent a better alternative since they release the $\mathrm{Zn}$ ions slower than the $\mathrm{ZnSO}_{4}$. Complementary studies comprising the pant life cycle are necessary to investigate the impact on productivity. This could be accomplished using $\mathrm{Zn}$ stable or radioactive isotopes.

\footnotetext{
Acknowledgements Brazilian Synchrotron Light Laboratory is acknowledged by providing beamtime at the XRF beamline (Proposal 20180037) as well as Dr. C. A. Perez for the assistance during the beamtime. The authors are grateful to the Laboratory of Electron Microscopy "Prof. Elliot Watanabe Kitajima" for providing the infrastructure for the SEM analysis and to Prof. E.A. de Nadai (CENA USP) for characterization of microparticles. The authors are also grateful to S.M. Savassa and M.F.H. Gomes (CENA USP) for assistance during the experiments.
}

Author contributions GSM performed the seed treatment, XRF and XANES experiments and treated the data. ESR processed the XANES data, assisted the XRF experiments and discussion. JPRM performed and discussed the SEM analysis and manuscript writing.
EA participated in XRF quantitative analysis and manuscript writing. MC performed the DTPA extraction and contributed to the discussion of the results. GSM organized the content and structure of the manuscript and wrote the text. HWPC designed and coordinated the study, assisted the writing, and reviewed the whole paper.

Funding This study was funded by São Paulo Research Foundation (FAPESP) Young Researchers Award (2015/05942-0), multiuser equipment (2015/19121-8), and Masters Scholarship (2017/163754). GSM received a scholarship funded by Agrichem do Brasil (Grant No. 102458).

\section{Compliance with ethical standards}

Conflict of interest On behalf of all authors, the corresponding author states that there is no conflict of interest.

\section{References}

1. FAO (2003) Trade reforms and food security: conceptualizing the linkages. Food and Agricultural Organization of the United Nations, Rome

2. Horlings LG, Marsden TK (2011) Towards the real green revolution? Exploring the conceptual dimensions of a new ecological modernisation of agriculture that could 'feed the world'. Glob Environ Chang 21:441-452. https://doi.org/10.1016/j.gloen vcha.2011.01.004

3. Godfray HCJ, Beddington JR, Crute IR, Haddad L, Lawrence D, Muir JF, Pretty J, Robinson S, Thomas SM, Toulmin C (2010) Food security: the challenge of feeding 9 billion people. Science 327:812-818. https://doi.org/10.1126/science.1185383

4. World Bank (2007) World development report 2008: agriculture for development. https://openknowledge.worldbank.org/handl e/10986/5990. Accessed 08 Oct 2019

5. FAO (2009) Global agriculture towards 2050. In: How to feed the world 2050. Food and Agricultural Organization of the United Nations, Rome

6. PAI (2011) Why population matters to food security. Population action international. https://pai.org/wp-content/uploa ds/2012/02/PAI-1293-FOOD_compressed.pdf. Accessed 08 Oct 2019

7. Day W, Audsley E, Frost AR (2008) An engineering approach to modelling, decision support and control for sustainable systems. Philos Trans R Soc B Biol Sci 363:527-541. https://doi. org/10.1098/rstb.2007.2168

8. Taiz L, Zeiger E (2010) Plant physiology. Sinauer Associates, Sunderland

9. Lepp NW (1981) Effect of heavy metal pollution on plants: metals in the environment. Applied Science Publishers Ltd., London

10. Hafeez B, Khanif YM, Saleem M (2013) Role of zinc in plant nutrition-a review. Am J Exp Agric 3:374-391. https://doi. org/10.9734/AJEA/2013/2746

11. Welch RM (1995) Micronutrient nutrition of plants. Crit Rev Plant Sci 14:49-82. https://doi.org/10.1080/713608066

12. Sillanpaeae $M(1990)$ Micronutrient assessment at the country level: an international study. In: Soil bulletin 63. FAO, Rome

13. Montalvo D, Degryse F, da Silva RC, Baird R, McLaughlin MJ (2016) Agronomic effectiveness of zinc sources as micronutrient fertilizer. In: Sparks DL (ed) Advances in agronomy, vol 139. Elsevier, San Diego, pp 215-267

14. Robson AD (1993) Zinc in soils and plants. In: Proceedings of the international symposium on 'zinc in soils and plants' held 
at the university of Western Australia, 27-28 September, 1993. Springer, Dordrecht

15. Farooq M, Wahid A, Siddique KHM (2012) Micronutrient application through seed treatments - a review. J Soil Sci Plant Nutr 12:125-142. https://doi.org/10.4067/s0718-951620120001000 11

16. Cakmak I (2008) Enrichment of cereal grains with zinc: agronomic or genetic biofortification? Plant Soil 302:1-17. https:// doi.org/10.1007/s11104-007-9466-3

17. Peters RJB, Bouwmeester $H$, Gottardo S, Amenta V, Arena M, Brandhoff P, Marvin HJP, Mech A, Moniz FB, Pesudo LQ, Rauscher $\mathrm{H}$, Schoonjans R, Undas AK, Vettori MV, Weigel S, Aschberger K (2016) Nanomaterials for products and application in agriculture, feed and food. Trends Food Sci Technol 54:155-164. https ://doi.org/10.1016/j.tifs.2016.06.008

18. Sabir S, Arshad M, Chaudhari SK (2014) Zinc oxide nanoparticles for revolutionizing agriculture: synthesis and applications. Sci World J. https://doi.org/10.1155/2014/925494

19. Prasad T, Sudhakar P, Sreenivasulu Y, Latha $P$, Munaswamy V, Reddy KR, Sreeprasad TS, Sajanlal PR, Pradeep T (2012) Effect of nanoscale zinc oxide particles on the germination, growth and yield of peanut. J Plant Nutr 35:905-927. https://doi. org/10.1080/01904167.2012.663443

20. Adhikari T, Kundu S, Rao AS (2016) Zinc delivery to plants through seed coating with nano-zinc oxide particles. J Plant Nutr 39:139-149. https://doi.org/10.1080/01904167.2015.10875 62

21. Mahdieh M, Sangi MR, Bamdad F, Ghanem A (2018) Effect of seed and foliar application of nano-zinc oxide, zinc chelate, and zinc sulphate rates on yield and growth of pinto bean (Phaseolus vulgaris) cultivars. J Plant Nutr 41:2401-2412. https://doi. org/10.1080/01904167.2018.1510517

22. Lin DH, Xing BS (2007) Phytotoxicity of nanoparticles: inhibition of seed germination and root growth. Environ Pollut 150:243250. https://doi.org/10.1016/j.envpol.2007.01.016

23. Homrich MS, Wiebke-Strohm B, Weber RLM, Bodanese-Zanettini MH (2012) Soybean genetic transformation: a valuable tool for the functional study of genes and the production of agronomically improved plants. Genet Mol Biol 35:998-1010. https://doi. org/10.1590/s1415-47572012000600015

24. AMIS (2019) AMIS market monitor, 66, March. Agricultural market information system. http://www.amis-outlook.org/filea dmin/user_upload/amis/docs/Market_monitor/AMIS_Marke t_Monitor_Issue_66.pdf. Accessed 08 Oct 2019

25. Hrnčírová M, Pospíšil J, Michalšpiláček MM (2013) Size analysis of solid particles using laser diffraction and sieve analysis. Eng Mech 20:309-318

26. Savassa SM, Duran NM, Rodrigues ES, de Almeida E, van Gestel CAM, Bompadre TFV, de Carvalho HWP (2018) Effects of ZnO nanoparticles on Phaseolus vulgaris germination and seedling development determined by $x$-ray spectroscopy. ACS Appl Nano Mater 1:6414-6426. https://doi.org/10.1021/acsanm.8b01619

27. Avelar SAG, Sousa F, Fiss G, Baudet L, Peske ST (2012) The use of film coating on the performance of treated corn seed. Rev Bras Sementes 34:186-192. https://doi.org/10.1590/S0101-31222 012000200001

28. de Melo APC, Seleguini A, Veloso V, Pereira JM (2015) Recobrimento de sementes de tomate com concentrações crescentes de polímero sintético. Ciênc Rural 45:958-963. https://doi. org/10.1590/0103-8478cr20131335

29. Dias MAN, Cicero SM (2016) Effect of copper carbonate and zinc oxide applied to seeds on copper and zinc uptake by maize seedlings. Bragantia 75:286-291. https://doi. org/10.1590/1678-4499.533
30. Abati J, Zucareli C, Foloni JSS, Henning FA, Brzezinski CR, Henning AA (2014) Treatment with fungicides and insecticides on the physiological quality and health of wheat seeds. J Seed Sci 36:392-398. https://doi.org/10.1590/2317-1545v36n41006

31. de Camargo OA, Moniz AC, Jorge JA, Valadares J (1986) Métodos de análise química, mineralógica e física de solos do Instituto Agronômico de Campinas. In: Boletim Técnico, 106. Instituto Agronômico de Campinas, Campinas

32. da Cruz TNM, Savassa SM, Gomes MHF, Rodrigues ES, Duran NM, de Almeida E, Martinelli AP, de Carvalho HWP (2017) Shedding light on the mechanisms of absorption and transport of $\mathrm{ZnO}$ nanoparticles by plants via in vivo $x$-ray spectroscopy. Environ Sci Nano 4:2367-2376. https://doi.org/10.1039/c7en00785j

33. Duran NM, Medina-Llamas M, Cassanji JGB, de Lima RG, de Almeida E, Macedo WR, Mattia D, de Carvalho HWP (2018) Bean seedling growth enhancement using magnetite nanoparticles. J Agric Food Chem 66:5746-5755. https://doi.org/10.1021/acs. jafc. 8 b00557

34. Johnson SE, Lauren JG, Welch RM, Duxbury JM (2005) A comparison of the effects of micronutrient seed priming and soil fertilization on the mineral nutrition of chickpea (Cicer arietinum), lentil (Lens culinaris), rice (Oryza sativa) and wheat (Triticum aestivum) in Nepal. Exp Agric 41:427-448. https://doi.org/10.1017/ s0014479705002851

35. Radchuk V, Borisjuk L (2014) Physical, metabolic and developmental functions of the seed coat. Front Plant Sci 5:510. https ://doi.org/10.3389/fpls.2014.00510

36. Smýkal P, Vernoud V, Blair MW, Soukup A, Thompson RD (2014) The role of the testa during development and in establishment of dormancy of the legume seed. Front Plant Sci 5:351. https:// doi.org/10.3389/fpls.2014.00351

37. Duran NM, Savassa SM, de Lima RG, de Almeida E, Linhares FS, van Gestel CAM, de Carvalho HWP (2017) X-ray spectroscopy uncovering the effects of $\mathrm{Cu}$ based nanoparticle concentration and structure on Phaseolus vulgaris germination and seedling development. J Agric Food Chem 65:7874-7884. https://doi. org/10.1021/acs.jafc.7b03014

38. Wang ZY, Xu LN, Zhao J, Wang XK, White JC, Xing BS (2016) CuO Nanoparticle interaction with Arabidopsis thaliana: toxicity, parent-progeny transfer, and gene expression. Environ Sci Technol 50:6008-6016. https://doi.org/10.1021/acs.est.6b01017

39. Alloway BJ (2008) Zinc in soils and crop nutrition. International Zinc Association, Brussels

40. Slaton NA, Wilson $C E$, Ntamatungiro $S$, Norman RJ, Boothe DL (2001) Evaluation of zinc seed treatments for rice. Agron J 93:152-157. https://doi.org/10.2134/agronj2001.931152x

41. Imran $M$, Garbe-Schonberg D, Neumann G, Boelt B, Muhling $\mathrm{KH}$ (2017) Zinc distribution and localization in primed maize seeds and its translocation during early seedling development. Environ Exp Bot 143:91-98. https://doi.org/10.1016/j.envex pbot.2017.09.001

42. Sparks DL (1995) Environmental soil chemistry. Academic Press, San Diego

43. Wang $P$, Menzies NW, Lombi E, McKenna BA, Johannessen B, Glover CJ, Kappen P, Kopittke PM (2013) Fate of ZnO nanoparticles in soils and cowpea (Vigna unguiculata). Environ Sci Technol 47:13822-13830. https://doi.org/10.1021/es403466p

Publisher's Note Springer Nature remains neutral with regard to jurisdictional claims in published maps and institutional affiliations. 